\title{
セファレキシンおよびアモキシシリン/クラブラン酸の追加採用が 救急外来の経口抗菌薬使用に与える影響
}

\author{
篠田康孝 ${ }^{* 1}$, 新井か子 $り^{1}$, 松岡知子 ${ }^{1}$, 森 卓之 $^{1}$, 吉田真也 ${ }^{1}$, 大橋健吾 ${ }^{1}$, 吉村知哲 ${ }^{1.2}$, 杉山 正 $^{2}$ \\ 大垣市民病院薬剂部 ${ }^{1}$, 岐阜薬科大学実践社会薬学 ${ }^{2}$
}

\section{Changing Trends in Oral Antimicrobial Use in the Emergency Department following the Introduction of Cephalexin and Amoxicillin/clavulanic Acid to the Hospital Formulary}

\author{
Yasutaka Shinoda*1, Kaori Arai ${ }^{1}$, Tomoko Matsuoka ${ }^{1}$, Takayuki Mori ${ }^{1}$, Shinya Yoshida ${ }^{1}$ \\ Kengo Ohashi ${ }^{1}$, Tomoaki Yoshimura ${ }^{1.2}$ and Tadashi Sugiyama ${ }^{2}$, \\ Department of Pharmacy, Ogaki Municipal Hospital ${ }^{1}$, \\ Laboratory of Pharmacy Practice and Social Science, Gifu Pharmaceutical University ${ }^{2}$
}

\author{
$\left[\begin{array}{l}\text { Received May 9, } 2016 \\ \text { Accepted August 30, } 2016\end{array}\right]$
}

The National Action Plan on Antimicrobial Resistance was implemented by the Ministry of Health, Labor and Welfare in Japan in 2016. The aim is to reduce the use of broad spectrum antibacterial drugs and optimize the use of oral antimicrobials. Ogaki Municipal Hospital has been promoting the use of cephalexin (CEX) and the combination of amoxicillin and clavulanate potassium (AMPC/CVA) since these drugs were added to the drug formulary in December 2012. In this study, we compared trends in oral antibiotic use in the emergency department before and after the addition of CEX and AMPC/CVA to the formulary. We observed a significant decrease in the average monthly consumption of third-generation cephalosporins (before: $264.3 \pm 58.2$ days; after: $108.5 \pm 35.2$ days; $P<0.01$ ), and of macrolides (before: $52.7 \pm 21.9$ days; after: $18.9 \pm 13.7$ days; $P<0.01$ ). Cost savings on oral antibiotics following the formulary revisions were calculated as 500,000 yen over three years. No difference in clinical effect was observed when comparing CEX, AMPC/CVA, and a third-generation cephalosporin. Therefore, we recommended the use of CEX and AMPC/CVA, according to the hospital formulary, in order to change trends in oral antibiotic use and achieve the objectives of the National Action Plan on Antimicrobial Resistance.

Key words — National Action Plan on Antimicrobial Resistance, cephalexin, amoxicillin clavulanate, oral antibiotics, antimicrobial stewardship

\section{緒 言}

院内採用薬の審議や決定には薬剤師が密接に関 与する分野であり，採用による将来的なメリット／ デメリットを予測して院内採用薬について決定する 必要がある. ${ }^{1)}$ 患者に対する薬剂使用に対しては病 院ごとに採用医薬品の制限を受け，特に救急外来 では診療時間などの関係でその傾向が強い. 五味 らは，院内採用抗菌薬を少なくすることが系統別抗 菌薬使用比率を変化させ, 偏った抗菌薬使用を是 正し, 薬剤耐性菌を減らすための 1 つの具体策で

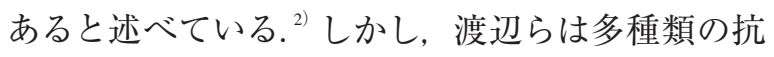
菌薬を揃え, 適応を守りながら, 適正に使用するこ とが重要であり, 単純な絞り込みは耐性菌抑制の目 的においては逆効果であることが多い, との見解を 示している. ${ }^{3)}$ 実際の報告として戸島らは, 注射用 抗菌薬の採用のうち, 第 4 世代セファロスポリン系 薬，カルバペネム系薬を削減，ペニシリン系薬とフ ルオロキノロン系薬を増加したところ, 系統別の使 用動向が変化し, 多剂耐性グラム陰性菌の一部の 検出数が減少傾向を示したことを報告している. ${ }^{4}$

世界的な抗菌薬消費データの解析から, 系統別

\footnotetext{
*テ503-8502 岐阜県大垣市南煩町4-86
} 
に比較した場合，日本では諸外国で使用量の少な いセファロスポリン系薬の使用量が約 50\%程度 と多く,ペニシリン系薬の使用は約 $10 \%$ と少な いことが報告されている（https://cddep.org/sites/ default/files/swa_2015_final.pdf, 2016 年 4 月 30 日). ${ }^{5}$ 当院救急外来においても同様の傾向があった，それ は，第 1 世代セファロスポリン系薬の採用が小児用 製剂のみであることや， $\beta$ ラクタマーゼ阻害薬配合 ペニシリン系薬が採用されていなかったことが理由 と考えた。 また，経口抗菌薬の適正使用に関する情 報提供が不足していることが挙げられた.

そこで，当院の採用経口抗菌薬を追加し，選択 肢を広げ，さらに適正使用に関する情報提供を行 うことで第 3 世代セファロスポリン系薬などの広 域スペクトル経口抗菌薬の使用減少を目指した. 具体的には，当院では，セファレキシン（CEX） およびアモキシシリン/クラブラン酸カリウム （AMPC/CVA）を 2012 年 12 月より採用とした. また，感染対策チームから経口抗菌薬の適正使用 に関する觔強会を開くなどし，その使用を促して いった。本研究では, 経口抗菌薬の追加採用とそ の使用の推進が救急外来での経口抗菌薬使用動向 に及ぼす影響について検討した。

\section{方 法}

\section{1. 当院における経口抗菌薬の採用医薬品の変化}

当院の CEX および AMPC/CVA 採用前後にお ける経口抗菌薬の採用医薬品を表 1 に示す.

\section{2. 経口抗菌薬の適正使用に関する勉強会の開催}

感染対策チームに所属する薬剤師が講師とな り，救急外来に所属する医師，看護師を対象に経 口抗菌薬適正使用推進について 1 年に 1 回勉強会 を開催した，当院救急外来では主に研修医が診療 に従事し，処方を行うことから，特に研修医に対 し，主な経口抗菌薬と処方すべき疾患，病態につ いての講習も 1 年に 1 回行った。勉強会は, CEX およびAMPC/CVA 採用後に定期的に行った。ま た, CEX および AMPC/CVA 採用後の経口抗菌薬 の使用状況についても追跡し, 情報提供を行った. 採用前に上記情報提供は行っていない.
表 1 採用経口抗菌薬

\begin{tabular}{|c|c|c|}
\hline 抗菌薬系統 & 一般名 & 規格 \\
\hline \multirow{3}{*}{ ペニシリン系薬 } & $\begin{array}{l}\text { ペニシリン G } \\
\text { カリウム }\end{array}$ & 40 万単位 /g 顆粒 \\
\hline & アモキシシリン & $\begin{array}{l}250 \mathrm{mg} \text { カプセル } \\
100 \mathrm{mg} / \mathrm{g} \text { 顆粒 }\end{array}$ \\
\hline & $\begin{array}{l}\text { アモキシシリン } \\
\text { クラブラン酸 } \\
\text { カリウム }\end{array}$ & $250 \mathrm{mg}$ 錠 \\
\hline \multirow{2}{*}{$\begin{array}{l}\text { 第 } 1 \text { 世代 } \\
\text { セファロスポリン } \\
\text { 系薬 }\end{array}$} & セファクロル & \\
\hline & セファレキシン & $\underline{500 \mathrm{mg} / \mathrm{g} \text { 顆粒 }}$ \\
\hline \multirow{3}{*}{$\begin{array}{l}\text { 第 } 3 \text { 世代 } \\
\text { セファロスポリン } \\
\text { 系薬 }\end{array}$} & セフジニル & $\begin{array}{l}100 \mathrm{mg} \text { カプセル } \\
100 \mathrm{mg} / \mathrm{g} \text { 細粒 }\end{array}$ \\
\hline & $\begin{array}{l}\text { セフカペン } \\
\text { ピボキシル }\end{array}$ & $\begin{array}{l}100 \mathrm{mg} \text { 錠 } \\
100 \mathrm{mg} / \mathrm{g} \text { 細粒 }\end{array}$ \\
\hline & $\begin{array}{l}\text { セフジトレン } \\
\text { ピボキシル }\end{array}$ & $\begin{array}{l}100 \mathrm{mg} / \mathrm{g} \text { 細粒 } \\
100 \mathrm{mg} \text { 錠 }\end{array}$ \\
\hline \multirow{5}{*}{$\begin{array}{l}\text { フルオロ } \\
\text { キノロン系薬 }\end{array}$} & レボフロキサシン & $\begin{array}{l}100 \mathrm{mg} / \mathrm{g} \text { 細粒 } \\
500 \mathrm{mg} \text { 錠 }\end{array}$ \\
\hline & ガレノキサシン & $200 \mathrm{mg}$ 錠 \\
\hline & シタフロキサシン & $50 \mathrm{mg}$ 錠 \\
\hline & モキシフロキサシン & $400 \mathrm{mg}$ 錠 \\
\hline & トスフロキサシン & $\begin{array}{l}150 \mathrm{mg} / \mathrm{g} \text { 細粒 } \\
150 \mathrm{mg} \text { 錠 }\end{array}$ \\
\hline \multirow{4}{*}{ マクロライド系薬 } & エリスロマイシン & $\begin{array}{l}100 \mathrm{mg} \text { 錠 } \\
200 \mathrm{mg} / \mathrm{g} \text { ドライシロップ }\end{array}$ \\
\hline & クラリスロマイシン & $\begin{array}{l}200 \mathrm{mg} \text { 錠 } \\
50 \mathrm{mg} \text { 錠 } \\
100 \mathrm{mg} / \mathrm{g} \text { ドライシロップ }\end{array}$ \\
\hline & アジスロマイシン & $\begin{array}{l}100 \mathrm{mg} / \mathrm{g} \text { 細粒 } \\
250 \mathrm{mg} \text { 錠 } \\
2 \mathrm{~g} \text { ドライシロップ }\end{array}$ \\
\hline & ロキシスロマイシン & $150 \mathrm{mg}$ 錠 \\
\hline \multirow{5}{*}{ その他 } & ミノサイクリン & $\begin{array}{l}20 \mathrm{mg} / \mathrm{g} \text { 顆粒 } \\
50 \mathrm{mg} \text { 錠 }\end{array}$ \\
\hline & ホスホマイシン & $\begin{array}{l}500 \mathrm{mg} \text { 錠 } \\
400 \mathrm{mg} / \mathrm{g} \text { ドライシロップ }\end{array}$ \\
\hline & ファロペネム & $200 \mathrm{mg}$ 錠 \\
\hline & ST 合剤 & $\begin{array}{l}\text { スルファメトキサゾール } \\
400 \mathrm{mg} \\
+ \text { トリメトプリム } 40 \mathrm{mg} \text { 錠 }\end{array}$ \\
\hline & クリンダマイシン & $150 \mathrm{mg}$ カプセル \\
\hline
\end{tabular}

太字下線は 2012 年 12 月採用

\section{CEX および AMPC/CVA 採用前後での系統 別経口抗菌薬使用量の変化}

CEX およびAMPC/CVA 採用前 2 年間（2010 年 12 月～ 2012 年 11 月） と採用後 3 年間（2012 年 12 月〜2015 年 11 月）を本研究の対象とした. 対象期間において救急外来に打ける経口抗菌薬の 使用動向を系統別に調査し, 月ごとの平均使用量 について採用前後で比較を行った，経口抗菌薬の 使用量についてはそれぞれの経口抗菌薬の使用量 （g）を集計し, WHO の定める標準使用量 (defined 
daily dose: DDD）で除したのち，合計することで DDD 単位に換算した（WHO Collaborating Center for Drug Statistics Methodology: ATC/DDD Index 2016, http://www.whocc.no/atc_ddd_index/, 2016 年 5 月 1 日). DDD が設定されていない経口抗菌薬は添 付文書の標準投与量を暫定の DDD として設定した.

\section{4. 経口抗菌薬費用削減効果}

対象期間における採用後の経口抗菌薬削減費用 を以下に基づいて算出した。

経口抗菌薬費用削減額 $=($ 採用前の 1 処方あた り平均経口抗菌薬使用金額 - 採用後の 1 処方あた り平均経口抗菌薬使用金額 $) \times$ 採用後の総経口抗 菌薬処方数

1 処方あたり経口抗菌薬使用金額については経 口抗菌薬総使用金額を経口抗菌薬総処方数で割る ことにより求めた。経口抗菌薬使用金額について は 2015 年現在の薬価により計算した.

\section{CEX および AMPC/CVA の処方理由および 臨床効果}

2015 年 10 月，11月における CEX および AMPC/ CVA の処方患者の疾患名について電子カルテよ り後ろ向きに調查した。また，代表的な疾患につ いて 2012 年 10, 11 月における第 3 世代セファロ スポリン系薬使用患者の臨床効果と, 2015 年 10, 11 月における CEX および AMPC/CVA 使用患者 との臨床効果の比較を行った．臨床効果の指標は 救急外来受診後 7 日間以内の入院率とした.

\section{6. 統計解析}

統計解析には EZR version1 26 ${ }^{6}$ を用い, 平均経 口抗菌薬使用量の比較には student- $t$ 検定を用いて 行った．また， $P<0.05$ を有意差とした．臨床効 果の比較についてはフィッシャーの直接確率検定 法を用いた。

\section{7. 倫理的配慮}

本研究は, 当院倫理審査委員会の承認を得て(受 付番号：20160324-5), 人を対象とする医学系研 究に関する倫理指針に従い, 研究を行った。

\section{結果}

\section{CEX および AMPC/CVA 採用前後での系統 別経口抗菌薬使用量の変化}

採用前 2 年間と採用後 3 年間の系統別月平均経 口抗菌薬使用量の比較に打いて, ペニシリン系薬 は採用前 $30.9 \pm 8.4$ (days)，採用後 $128.3 \pm 61.1$ (days) と有意に増加した $(P<0.01)$. 同様に第 1 世代セファロスポリン系薬は採用前 $3.1 \pm 3.7$ (days)，採用後 $77.3 \pm 38.1$ (days) と有意に増 加した $(P<0.01)$. それに対し, 第 3 世代セファ ロスポリン系薬は採用前 $264.3 \pm 58.2$ （days）, 採 用後 $108.5 \pm 35.2$ (days) と有意に減少した（ $P$ <0.01). また，マクロライド系薬についても採 用前 $52.7 \pm 21.9$ (days)，採用後 $18.9 \pm 13.7$ （days） と有意に減少していた。しかし, キノロン系薬や その他の経口抗菌薬系統については採用前と採用 後で有意な増減はなかった（図 1)。また，採用 前後で月平均全経口抗菌薬使用量に有意な増減は 見られなかった(採用前 2 年間 $572.2 \pm 86$ (days)， 採用後 3 年間 $532.0 \pm 81.6$ (days), 平均 \pm 標準偏 差）（図 2). 抗菌薬処方件数は 4,269 件（採用前 2 年), 4,198 件 (採用前 1 年), 3,852 件（採用後 1 年), 3,871 件 (採用後 2 年), 3,881 件（採用後 3 年）と採用後に減少が見られた。また，12 歳未 満の小児患者の割合は $32 \%$ (採用前 2 年), $34 \%$ (採 用前 1 年), $28 \%$ (採用後 1 年), $25 \%$ (採用後 2 年), $25 \%$ （採用後 3 年）と採用後に減少が見られた。

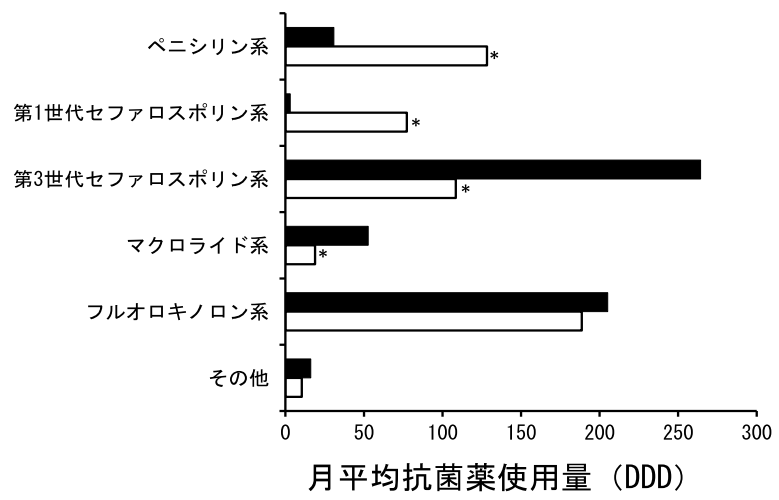

図 1 採用前後での平均経口抗菌薬使用量の系統ご との比較

採用前， $\square$ 採用後 $* P<0.01 \mathrm{vs}$ 採用前. student $t$-test 


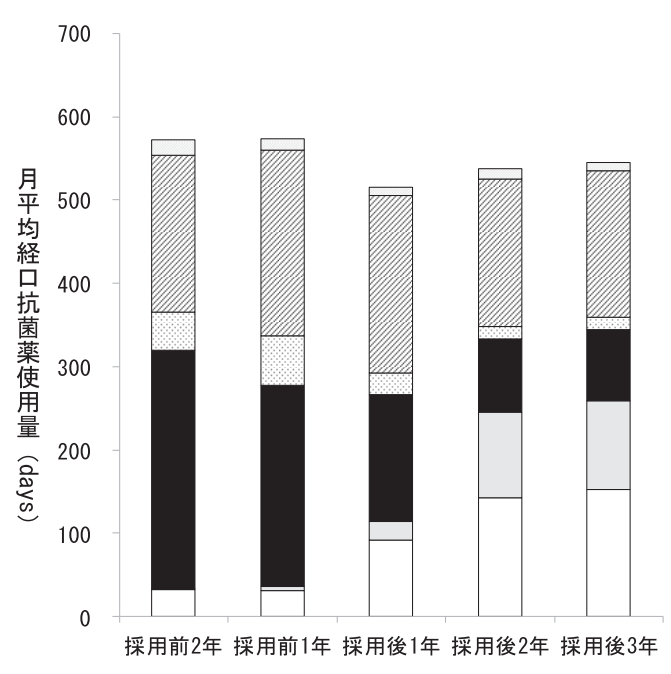

図2月平均経口抗菌薬使用量の推移 全体の月平均抗菌薬使用量に採用前後で有意差はなかった. student $t$-test

$\square$ ペニシリン系 $\square$ 第 1 世代セファロスポリン系

第 3 世代セファロスポリン系 圆マクロライド系

フルオロキノロン系 $\square$ その他

\section{2. 経口抗菌薬費用削減効果}

採用前 2 年間の総経口抗菌薬使用金額は $5,329,863$ 円, 採用後 3 年間の総経口抗菌薬使用 金額は 6,431,629 円であった. 総経口抗菌薬処方 数は採用前 2 年間で 8,467 件, 採用後 3 年間で 11,006 件であった。1 処方あたりの平均経口抗菌 薬使用金額の差は 629 (採用前) -584 (採用後 $)=$ 45（円）であった。よって, 経口抗菌薬費削減額 は $45 \times 11,006=496,659$ (円）と算出された.

\section{CEX および AMPC/CVA の処方理由および 臨床効果}

2015 年 10，11月における CEX および AMPC/ CVAの使用患者はそれぞれ 199例, 56例であった. CEX の処方理由として最も多かったものは外傷 後感染予防であり，160例（80\%), 次いで皮虐 感染症 28 例（14\%）であった. AMPC/CVA の処 方理由として最も多かったものは動物咬傷に対す る感染予防であり，30例（53\%）であり，次い で外傷後感染予防が 10 例 (18\%), 肺炎が 8 例 （14\%）であった。

2012 年 10,11 月において第 3 世代セファロス ポリン系薬を使用している患者のうち, 外傷後感 染予防として処方を受けていた患者は 178 例, 動 物咬傷に対する感染予防として処方を受けていた
患者は 42 例であった. 外傷後感染予防として CEX を使用していた患者の年齢は50（32-67） 歳であり, 第 3 世代セファロスポリン系薬を使用 していた患者は48（30－69）歳であった（中央 值 (4 分位值))。また, 男性の割合はそれぞれ $68 \% ， 65 \%$ と同等であった。処方後 1 週間以内の 入院患者数は, 外傷後感染予防として CEX の処 方を受けていた患者では 160 例中 2 例, 第 3 世代 セファロスポリン系薬の処方を受けていた患者で は 178 例中 3 例で, その割合に有意差はなかった.

動物咬傷に対し, AMPC/CVAを使用していた 患者の年齢は $45 （ 22-71 ）$ 歳であり, 第 3 世代 セファロスポリン系薬を使用していた患者は 51 (26-68) 歳であった (中央值 (4 分位值))。また, 男性の割合はそれぞれ $47 \%, 52 \%$ と同等であっ た．動物咬傷に対する感染予防として経口抗菌薬 を投与されていた患者の中に処方後 1 週間のうち に入院していた例は存在しなかった.

\section{考察}

平成 28 年 4 月 5 日, 厚生労働省から薬剂耐性 対策アクションプラン（2016２020）が打ち出 された（厚生労働省：薬剤耐性（AMR）対策ア クションプラン 2016〜2020, 国際的に驚異となる 感染症対策関係閣僚会議, 2016 年 4 月 5 日. http:// www.mhlw.go.jp/file/06-Seisakujouhou-10900000Kenkoukyoku/0000120769.pdf, 2016 年 4 月 30 日). そのなかで, 我が国における問題点として, 他国 と比して幅広いスペクトルを持つ第 3 世代セファ ロスポリン系薬の使用割合が多いことやペニシリ ン系薬の使用割合が少ないことが挙げられてい る.そのことから, 2013 年と比べ 2020 年までに 経口第 3 世代セファロスポリン系薬の使用を $50 \%$ 削減することなどが具体的な目標值として設 定されている。 また，外来における経口抗菌薬処 方の多くは不適正との報告もあり, 経口抗菌薬の 適正使用の必要性については多くの国で課題と

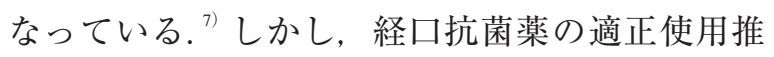
進の方法に関しては情報が少ない。

また，2016年 4 月 13 日に米国感染症学会と米国 医療疫学学会から示された Antimicrobial stewardship 
guideline がアップデートされたが，抗菌薬適正使用 推進のために推奨度の高い方法として，それまでと 同様に「抗菌薬の使用制限」と「介入とフィードバッ ク」が抗菌薬適正使用を推進する 2 大戦略とされ ている. ${ }^{8)}$ これらの方法の有用性は主に入院患者に 対してのエビデンスが示されているものの, 救急外 来患者に対して適応することは人員的にも時間的に も現実的ではない. 従って, 外来患者に対する経口 抗菌薬の適正使用推進の方法を考える必要がある.

本研究では，CEXおよびAMPC/CVA の採用前 後で第 3 世代セファロスポリン系薬の使用が顕著 に減少した。薬剤耐性対策アクションプランにお いて, 厚生労働省は抗菌薬適正使用に対しての目 標を幾つか定めている，その目標として，「2020 年の経口セファロスポリン系薬，フルオロキノロ ン系薬，マクロライド系薬の人口千人あたりの 一日使用量を 2013 年の水準から $50 \%$ 削減する.」 と記載されている。本検討において, CEX およ びAMPC/CVA の採用前後でセファロスポリン系 薬，マクロライド系薬の月平均使用量がそれぞれ 30.5\%，64\%減少した。第 3 世代セファロスポリ ン系薬のみで計算すると約 $59 \%$ 減少しており, これは元来第 3 世代セファロスポリン系薬, マク ロライド系薬が使用されていた症例において, 広 域スペクトル経口抗菌薬の使用量減少, 狭域スペ クトル系薬の適正使用を推進する情報提供を行っ た結果，新たに採用された CEX および AMPC/ CVA が選択されるようになったためであると考え られる。よって，CEX および AMPC/CVA の採用と その使用の推進は, 薬剤耐性対策アクションプラ ンの目標を達成するためにも意義のあることと考え られる。しかし，フルオロキノロン系薬については 2 郕の採用前後で変化がなかったこれは，CEX および AMPC/CVA で治療可能な症例であっても, 1 日 1 回の使用により効果を発現する簡便なフルオ ロキノロン系薬から切り替えが進まなかったことが 原因であると考えられる。 また, 経口抗菌薬の全使 用量にも変化がなかった。薬剤耐性対策アクション プランに含まれる「全抗菌薬使用量を 3 分の 2 に 削減する」という目標の達成には CEX および AMPC/CVA の採用とその使用の推奨以外に個々の 症例に対し介入とフィードバックを行うことや，
不適正な経口抗菌薬の処方率をほかの医師と比較 できるようなシステムを活用するなど別の対策が 必要と考えられ, 今後の課題である. ${ }^{9}$ 10)

抗菌薬費削減は抗菌薬適正使用の重要なアウト カムの 1 つである。 今回採用となった CEXや AMPC/CVA は第 3 世代セファロスポリン系薬よ りも成人 1 日当たりの使用に抒いて安価である

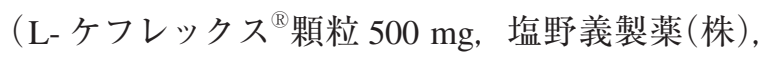
大阪, 1 日 2 回：158.8 円, オーグメンチン ${ }^{\circledR}$ 錠 250RS, グラクソ・スミスクライン(株), 東京, 1

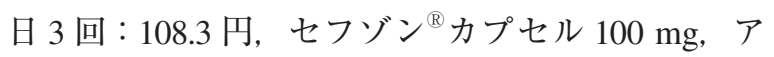
ステラス製薬(株), 東京, 1 日 3 回：189 円, フロモッ クス ${ }^{\circledR}$ 錠 $100 \mathrm{mg}$, 塩野義製薬(株), 1 日 3 回：165 円， 2015 年における薬価). 今回の検討では CEX および AMPC/CVA の採用とその使用の推奨によ る経口抗菌薬削減額は 3 年間で約 50 万円と算出 された。この金額は，2015 年現在の薬価で計算 したものである。採用前時点の薬価は 2015 年現 在の薬価よりも僅かではあるが高いため, 採用前 時点の経口抗菌薬使用金額をその当時の薬価で計 算した場合には, 抗菌薬削減額は今回の算出額よ りも僅かに大きくなると想定される，以上より， 第 3 世代セファロスポリン系薬の使用量が減少 し, 追加採用の安価な経口抗菌薬の使用量が増加 したため, 経口抗菌薬使用金額を減少させ，医療 費削減につながる可能性も示唆される。

本研究では CEX および AMPC/CVA の処方理由 について調查することで適正に使用されているか についても検討した。調查の結果, CEX および AMPC/CVA の処方理由には外傷後における感染予 防や皮虐感染症, 動物咬傷が多かった. 外傷後の 感染予防や皮虐感染症に対しては, ブドウ球菌を はじめとするグラム陽性球菌をターゲットとする場 合が多く, サンフォードガイドラインなどに抒いて も第 1 世代セファロスポリン系薬, ペニシリン系薬 が第 1 選択とされ，腸内細菌などにも抗菌スペクト ルを持つ第 3 世代セファロスポリン系薬の使用は 不適切とも考えられる. ${ }^{11)}$ 同様に, イヌ/ネコなど の動物咬傷における感染予防に対する第 1 選択は AMPC/CVA であり, 第 3 世代セファロスポリン系 薬は推奨されていない. ${ }^{12)}$ 患者の重症度など患者背 景に関しての情報が不足しているため, 一概には 
言えないが, 本検討内での実際の臨床効果につい て CEX および AMPC/CVA と第 3 世代セファロス ポリン系薬の間には有意な差はなかった.より狭い 抗菌スペクトル, より推奨度の高い経口抗菌薬選 択を行っていることからも CEX および AMPC/CVA 採用とその使用の推進は適正使用に繋がっている と考えられる. 勉強会では，ガイドラインに基づく 抗菌薬適正使用の推進を重要視しており, 本結果 と一致していると考えられる。しかし, 不要な経口 抗菌薬投与に対しての影響については本検討内で は言及できず，今後の検討課題である.

本報告では 3 年という短い期間，かつ救急外来 での取り組みであり，CEX およびAMPC/CVAの 採用およびその使用促進による耐性菌の動向につ いては報告できなかった。しかしながら，偏った 抗菌薬の使用は耐性菌発現と密接にかかわってお り, 均一な異種抗菌薬系統の使用（antimicrobial heterogeneity）は耐性菌の減少に寄与するとの報 告もある. ${ }^{13)}$ 第 3 世代セファロスポリン系の不適 切な使用は extended-spectrum $\beta$-lactamase 産生菌 の発生リスクになり得ることが言われている. ${ }^{14)}$ 故に，今回の CEXおよびAMPC/CVAの採用お よびその使用促進による第 3 世代セファロスポリ ン系薬の偏った使用の抑制は耐性菌の減少に寄与 する可能性も考えられる。

\section{利益相反}

開示すべき利益相反はない.

\section{引用文献}

1）草間真紀子, 赤沢 学, 津谷喜一郎, 医療機関に おける採用医薬品集作成と医薬品採否に関する 実態調査 一過去10年間の変遷を踏まえて一, 臨床薬理, 2012, 43, 43-49.

2）五味晴美, 米国における抗菌薬使用制限一その 現状と問題点 -, INFECTION CONTROL, 2005, 14, 1003-1007.

3）渡辺 彰, 病院採用抗菌薬品目数の絞り込みは 是か非か? 耐性菌抑制の観点から, 感染と抗 菌薬, 2004, 7, 206-211.

4）戸島洋一, 松田俊之, 河井良智, 服部万里子, 注射 用抗菌薬のコントロールと薬剤耐性菌検出数一耐
性緑膿菌に注目して, 環境感染, 2005, 20, 188-192.

5) Van Boeckel TP, Gandra S, Ashok A, Caudron Q, Grenfell BT, Levin SA, Laxminarayan R, Global antibiotic consumption 2000 to 2010: an analysis of national pharmaceutical sales data, Lancet Infect Dis, 2014, 14, 742-750.

6) Kanda $Y$, Investigation of the freely-available easyto-use software "EZR" (Easy R) for medical statistics, Bone Marrow Transplant, 2013, 48, 452-458.

7) Shapiro DJ, Hicks LA, Pavia AT, Hersh AL, Antibiotic prescribing for adults in ambulatory care in the USA, 2007-09, J Antimicrob Chemother, 2014, 69, 234-240.

8) Barlam TF, Cosgrove SE, Abbo LM, MacDougall C, Schuetz AN, Septimus EJ, Srinivasan A, Dellit TH, Falck-Ytter YT, Fishman NO, Hamilton CW, Jenkins TC, Lipsett PA, Malani PN, May LS, Moran GJ, Neuhauser MM, Newland JG, Ohl CA, Samore MH, Seo SK, Trivedi KK, Implementing an Antibiotic Stewardship Program: Guidelines by the Infectious Diseases Society of America and the Society for Healthcare Epidemiology of America, Clin Infect Dis, 2016, doi: 10.1093/cid/ciw118.

9) Gerber JS, Prasad PA, Fiks AG, Localio AR, Grundmeier RW, Bell LM, Wasserman RC, Keren R, Zaoutis TE, Effect of an outpatient antimicrobial stewardship intervention on broad-spectrum antibiotic prescribing by primary care pediatricians: a randomized trial, JAMA, 2013, 309, 2345-2352.

10) Meeker D, Linder JA, Fox CR, Friedberg MW, Persell SD, Goldstein NJ, Knight TK, Hay JW, Doctor JN, Effect of Behavioral Interventions on Inappropriate Antibiotic Prescribing Among Primary Care Practices: A Randomized Clinical Trial, JAMA, 2016, 315, 562-570.

11） 戸塚恭一, 橋本正良, “日本語版サンフォード感 染症治療ガイド2016”, ライフサイエンス出版, 東京, 2011, pp1-346.

12) Morgan M, Palmer J, Dog bites, BMJ, 2007, 334, 413-417.

13) Takesue $Y$, Nakajima K, Ichiki K, Ishihara M, Wada Y, Takahashi Y, Tsuchida T, Ikeuchi H, Impact of a hospital-wide programme of heterogeneous antibiotic use on the development of antibiotic-resistant Gramnegative bacteria, J Hosp Infect, 2010, 75, 28-32.

14) Rawat D, Nair D, Extended-spectrum $\beta$-lactamases in Gram Negative Bacteria, J Glob Infect Dis, 2010, 2, 263-274. 